\title{
KÖNYVSZEMLE
}

Michael Linden - Max Rotter - Kai Baumann - Barbara Lieberei:

Posttraumatic embitterment disorder. Definition, evidence, diagnosis and treatment

Hogrefe, Cambridge, MA, Göttingen, 2007, 155 oldal, ára: 2,98 \$ ISBN 88937-344-2

A szerzői munkacsoport Berlinben (annak keleti részében) dolgozik, és ott figyeltek fel egy tünetegyüttesre, amely ott nagy gyakorisággal fordul eló. Ez krónikus lehangoltság, amely hosszú munkaképtelenséget okoz, különféle pszichés és szomatikus panaszokkal jár együtt, gyakran kémiai anyag abúzus is kíséri, és amely pszichoszociális traumával függ össze, rendszerint státusvesztéssel, munkanélküliséggel, önértékelési zavarral, amelyet a páciens igazságtalanságnak él meg. Az ôt ért eseményekkel tartósan és ismételten foglalkozik, azok értelmezési módját illetóen nem befolyásolható, és ez a terápiát nehézzé teszi. Nyilvánvalóan adaptációs zavarról van szó, de ez nem sorolható be a poszttraumás stressz-zavar (PTSD) kategóriájába, hiszen a sérelmesnek átélt esemény inkább az illetó egyéni felfogásában túnik különösnek és súlyosnak, nem jelentett vitális veszélyt vagy érzelmi túlterhelést okozó traumát, a többség hasonló élményeket képes feldolgozni. A depresszív szimptomatika ellenére az állapot nem tekinthetô depressziónak, ugyanis a hangulat változó, és a normális emocionális reakciók elóhívhatók. 
A szerzók szerint célszerú külön betegségtani egységnek tekinteni a tüneti képet, mert sajátos az etiológiája, diagnózisa és terápiája. Poszttraumás elkeseredettségi zavarnak nevezték (Posttraumatic Embitterment Disorder $=$ PTED) a jelenséget, mert a panaszoknak valamilyen életesemény miatti huzamos és folyamatos (bár fluktuáló) elkeseredés az alapja, amelyek miatt a személy áldozatnak érzi magát, és amellyel szemben tehetetlen. A sérelem tulajdonképpen nem igazi trauma, inkább kritikus életeseménynek nevezhetó, mivel megterhelésében valóban van valami szokatlan és zavaró, de az átlag, a többség számára inkább kihívás, életprobléma, semmint katasztrófa. A traumatikus életesemény miatti csalódottság elemzéséból kiderül, hogy a megkeseredettség alapja a társadalommal, a szociokulturális valósággal kapcsolatos alapvetố hiedelmek (basic beliefs), illetve a megszokott értékrendszerrel összefüggő elbizonytalanodás.

A berlini fal leomlása után a keletnémet területen lakók közül sokan éltek meg alapvetó élethelyzeti változásokat - rendszerint romlást - munkakörülményeikben, társadalmi státusukban vagy életperspektíváikban, és rendszerint erre vonatkoztatva alakultak ki a szindróma tünetei. De a kórkép nem okvetlen politikai vagy intézményes változási helyzetek nyomán jön létre, hanem kapcsolati veszteség, családi szerepekben beálló módosulások nyugdijazás stb. következtében is. Így a PTED nem specifikusan "keletnémet” tüneti állapot, csak ott az elmúlt kb. másfél évtizedben gyakrabban és jellegzetes formában mutatkozik.

Ez a fajta tünetcsoport a korábbi nemzedékekben is gyakran elófordult, ilyen eseteket soroltak a reaktív depresszió kategóriájába, és ilyeneket írtak le különbözó munkaügyi és biztosítási kárigények hátterében.

A szerzók ezt az állapotot külön betegségtani egységként határozták meg, a DSM-IV, ill. a BNO-10 logikája szerint. Négy fő kritériumot szabtak meg: kivételes, negatív életesemény a betegség kezdete elótt, a beteg az eseményt panaszai okának tartja, az esemény az ő felfogásában súlyosan igazságtalan, emiatt elkeseredettség áll fenn és a téma beteget felizgatja, valamint az, hogy más pszichiátriai betegség nem indokolja a tüneteket. További kilenc kritérium szól egyéb, járulékos tünetekról és sajátosságokról. A diagnózist legalább háromhavi fennállás után lehet kimondani, és ehhez a napi rutin és a fontosabb társadalmi szerepek valamelyikében megfigyelhetố zavar észlelése is szükséges.

A szerzók több oldalról is vizsgálták a kórképet. Esettanulmányokon kívül elóször 17 olyan beteget tanulmányoztak, akik megfeleltek a kritériumoknak, majd pedig klinikájuk kb. 1200 bennfekvóként kezelt esetéból 50 PTED beteget és hozzájuk másik 50 illesztett kontrollesetet mértek fel, és ennek során finomították kritériumaikat. A szimptomatika a PTED ese- 
tekben igen változó volt, de a fó kritériumok egyértelmúen megtalálhatók voltak. A negatív életeseménnyel kapcsolatosan a szerzók gyakran használják azt a fogalmazásmódot, hogy emiatt, illetve ennek nyomán a betegeknek át kellett szervezniük, illetve szerkeszteniük (reorganize) biográfiájukat. A nozológiai és a diagnosztikus vizsgálatok után a szerzók érdekes felmérést is végeztek: egy vonat (amely Berlinból Frankfurt am Oder irányába tartott) utasai közül 158 embert vizsgáltak meg klinikai interjú és a szerzócsoport által kialakított PTED önminősítő skála segítségével, és kb. az esetek negyedét találták besorolhatónak az új diagnosztikus egységbe. További hasonló vizsgálatokat is terveznek.

Mint az epidemiológiai megközelítésból is kitúnik, a szerzók a kórképet spektrális jellegúnek tartják, és feltételezik, hogy a problémát sokan leküzdik, és sokan vannak szubklinikai szinten. Megfigyeléseik alapján terápiás eljárásokat alakítottak ki. Vizsgálták az alapvetố hiedelmek kérdését, ez a modern kognitív lélektanban gyakran tárgyalt téma. Különbözó meghatározásai vannak a fogalomnak, de lényegében ugyanarra vonatkozik, amit Antonovsky a „szalutogenezis” koncepcióban leírt élményfeldolgozási folyamatok kapcsán említ, vagy amely az igazságosságra vagy a bizalomra vonatkozó kutatásokban körvonalazódik. E hiedelmek, feltevések döntik el, illetve alakítják ki a szubjektív átélésben a dolgok „értelmét". A vizsgálatok szerint a PTED esetekben az alapvető hiedelmek általában merevek, a személyiség erôsen hajlik a perfekcionizmusra, a teljesítményorientáltságra.

A szerzók még egy érdekes kognitív pszichológiai megközelítést használnak, az ún. „bölcsességpszichológiát” (wisdom psychology), amelynek kutatása különösen Baltes és Staudinger munkássága nyomán terjedt el. Ennek elmélete szerint minden emberben kialakul egy ismeret- és készséghalmaz, amely a mindennapi élet rutinját biztosítja. Ez különbözó fejlettségú lehet. Minél fejlettebb a „bölcsesség” valakiben, annál nagyobb a problémamegoldó képessége, annál ellenállóbb a stresszekkel szemben, és annál könnyebben leküzdi ezek következményeit. A PTED esetekben a „bölcsesség” mértéke alacsonyabb, mint az átlagos (az esetekkel összehasonlítható átlagé), különösen kognitív és érzelmi vonatkozásban. A szerzôk azt találták, hogy a következó vetületekben fejletlenebb vagy kevésbé adekvát e páciensek mentalitása: perspektívaváltási képesség, empátia, az érzelmek észlelése és elfogadása, a dolgok kontextusba állítása, az értékek relativizációja, valamint a bizonytalanság elfogadása, de vannak deficitek a derú képességében és a hosszú távú életperspektívákban, és általában a tényszerú tájékozottságban is. Ez beszúkülést, merevséget okoz, és hajlamosít a kritikus, negatív életeseményekkel kapcsolatos sérülékenységre. 
A tünetegyüttes a szokványos terápiás módszerekre nehezen reagál. A „bölcsességlélektani” megközelítés a szerzók számára azért is volt fontos, mert ennek alapján kognitív terápiás módszert alakítottak ki, ezt bölcsességterápiának (wisdom therapy) nevezték, mely egyfajta pszichoedukatív tréningeljárás, amelynek kapcsán mintegy gyakoroltatják a nehezen megoldható életproblémák értelmezését és leküzdését, segítik az érzelmek felismerését és elfogadását, a perspektívaváltást, a kontextusok figyelembevételét és a bizonytalanság elviselését. Egy sor elképzelt élethelyzeti nehézséget és dilemmát szedtek listába, és ezeket beszélik meg a páciensekkel. A módszer leírását a könyv tartalmazza. Természetesen a hatékonyságról egyelôre nem tudnak számot adni.

A kötet kitúnő munka, egész felépítésében nagyon modern, alkalmazkodik a DSM-rendszer diagnosztikai logikájához, mindent röviden, pregnánsan, operatív módon ír le, az idézett irodalom releváns, a lényeget tartalmazza. Az egész munka azért érdemel figyelmet, mert mindenki tudja, hogy a mai nozológiai kategóriák elégtelenek, és most talán sikerült kiemelni egy gyakori jelenséget, amely ma bizonyára kallódik és elsikkad az ellátási hálózatban. A gyakorlatban nálunk sok ilyen esetet láttunk, különösen a régi „neurózisosztályokon”, és a rendszerváltás után nálunk is megjelentek státus- és perspektívavesztett emberek diffúz, bizonytalan panaszokkal, amelyek egy-egy negatív életeseményhez kötődtek, és élményfeldolgozási, adaptációs zavarként voltak értelmezhetók (sokuk már mindenféle kezelésen átesett, leszázalékolást kívánt, sok tüneti gyógyszert kapott, köztük antidepresszánsokat, hiszen a depresszió diagnózisát ilyen estekben könnyú elóvenni). A könyvet tehát érdemes tanulmányozni.

A diagnózis lényegében képes megközelíteni az összefüggést a társadalmi változások és az ebból következő élethelyzeti stresszek és bizonyos tüneti reakciók között. Régen az ilyen esetek „utilitárius” neurózisként szerepeltek (a leszázalékolási igény vagy kényszer miatt), vagy pedig reaktív depresszió kórisméjét kapták. A jellegzetes esetek mindig munkahelylyel, pályával, hivatással kapcsolatos konfliktusok és veszteségek nyomán álltak eló.

A „létezó szocializmus” évtizedeit a magyar szakmai térben átéltek emlékezhetnek rá, hogy a "neurózisok” értelmezésében ismételten felmerült a kognitív deficit mint élettapasztalati hiány, mintegy ",butaság”, sokan az elégtelen családi és közösségi szocializációt tették felelóssé a tüneti állapotokért (néha a tanuláselméleti magyarázatot szembeállítva az akkoriban divatos pszichoanalitikus felfogással, amely a korai traumák oki szerepét hangsúlyozta), de voltak szakemberek, akik még agykamratágulatot vagy kéregsorvadást is kerestek - az akkor meglévố képalkotási lehetôségek mellett - az idült neurózisokban. Valami hasonló klinikai benyomásból 
indulhattak tehát ki, mint ez a szerzócsoport, amely most jó koncepciót és megfelelő diagnosztikai és terápiás technikákat talál.

Dr. Buda Béla

1537 Budapest, Pf. 434

E-mail: buda.bela@ndi-int.hu

Demetrovics Zsolt - Urbán Róbert - Kökönyei Gyöngyi (szerk.):

\section{Iskolai egészségpszichológia}

L'Harmattan Kiadó, Budapest, 2007, 314 oldal, ára: 2400 Ft ISBN 9789639683723

A kötetet mindazoknak ajánlom, akik érdeklődnek az iskolai egészségpszichológia integratív tudományága iránt, de leginkább a közoktatás azon szereplóinek, akik hatékonyabbá kívánják tenni egészségnevelô, -fejlesztô tevékenységüket. E mú egy konferencia összefoglalója, amely az egészségfejlesztố programokkal kapcsolatos kutatási eredményekre fókuszált, és ahol megvalósult pozitív példákról hangzottak el beszámolók. Olyan, megfelelố kutatási háttérrel alátámasztott programok bemutatására vállalkozik a könyv, amelyek pontosan dokumentáltak és kiértékeltek, ahol törekedtek a minôségbiztosításra és eredményvizsgálatokra. A kötet elméleti áttekintést ad az egészségpszichológia tudományterületéról, annak az iskolai egészségfejlesztési munkában hasznosítható gyakorlatias, „felhasználóbarát" szemléletéról. A könyv interdiszciplináris és integratív szemléletét erôsíti az a tény, hogy a tanulmányok, előadások szerzői az egészségtudományok és a pedagógia sokféle területéról érkeztek.

A kötet a 2005-ben Budapesten az ELTE Dísztermében megtartott „II. Egészségpszichológiai találkozó" összefoglalója. Az „Iskola és egészségpszichológia" tematikus címet viseló konferencián elhangzott elóadásokat és más, olyan kutatásokat, amelyek nem fértek bele a konferencia programjába, egy csokorba szerkesztett kötetként kapja kézhez az olvasó. Különösen figyelemreméltó az a törekvés, hogy egy konferenciának van nyomtatott utóélete, és mindez szerkesztett, élvezhetó formában. E munka alapjául szolgáló konferenciát az „Egészségpszichológia Magyarországon: Oktatás, kutatás, együttmúködés" címú konferencia elózte meg 2004-ben, amelyet az ELTE Személyiség- és Egészségpszichológiai Tanszéke szervezett. A konferencia célja az volt, hogy a különbözó kutatócsoportok és oktatási intézmények közötti kommunikációt elősegítse, 
ezzel is jobb esélyeket teremtve a téma fejlődésének, hazai terjedésének, és az együttmúködésnek.

Maga a kötet négy nagyobb tematikus egységre oszlik. Az elsó rész tanulmányai az iskola, az egészségpszichológia és az egészségfejlesztés közös metszetét kívánják meghatározni. A tanulmányok egyike, Buda Béla írása rámutat arra, hogy az iskolai egészségfejlesztéshez nélkülözhetetlen a pedagógia és a pszichológia összefogása. A pedagógusok kiemelkedó szerepét nem lehet eléggé hangsúlyozni az egészségfejlesztés hatékony megvalósulásában, mivel az ô személyük kínál alapot a tanulók egészséges életmódra való neveléséhez; ezért nélkülözhetetlen a tanárok egészségének védelme és személyiségük fejlesztése.

A kötet második részében az egészségpszichológiai kutatások összefoglalásából találunk tanulmányokat. Ezek közül szeretnék a teljesség igénye nélkül kiemelni néhány tanulmányt. Pikó Bettina a pozitív pszichológia szemléletét alkalmazza a serdülókori egészségmagatartás magyarázatára. A pozitív pszichológia a rizikófaktorok helyett a protektív faktorokat hangsúlyozza a jóllét és a viselkedés alakulásában. Kökönyei Gyöngyi tanulmányában az önértékelés témakörét foglalja össze. Az önértékelés alacsony mértéke komoly sebezhetôséget jelenthet a rizikómagatartásokat illetóen, és gyengítheti a deviánsabb kortársak nyomásával szembeni ellenállást. Az önértékelésre vonatkozó nemzetközi és hazai kutatások eredményeinek ismerete lehetôséget kínál arra, hogy az önértékelésre vonatkozó intervenciók is az egészségfejlesztô program integráns részévé válhassanak. Török Szabolcs és munkatársainak empirikus munkája a krónikus betegségben szenvedó gyermekek részére szervezett rekreációs táborok hatásait vizsgáló kutatási eredményei rendkívül biztatóak. A nyári táborban részt vett gyermekek önértékelése és énhatékonysága a tábor végére nôtt, és ez a pozitív változás utánkövetéssel is tartósnak bizonyult.

A harmadik rész a serdülókori legális és illegális szerhasználat előfordulásáról és kialakulásának, fennmaradásának magyarázó tényezóivel foglalkozik. Urbán Róbert a serdülőkori dohányzás jelenségét világítja meg tanulmányával. A dohányos „karrierek" vagy fejlődési útvonalak ismerete hasznos információval szolgálhat, hiszen a rendszeres dohányzás kialakulása, stabilizálódása hosszú folyamat. A folyamat különbözó szintjein tartók esetében más-más módon érdemes a prevenciós programok elemeit alkalmazni. Elekes Zsuzsanna a 9-10. évfolyamon tanuló gyerekek alkoholfogyasztási szokásait az ESPAD-vizsgálat eredményei alapján ismerteti. A lerészegedés és nagyivás 1995-ös, 1999-es és 2003-as adatainak összevetése egyértelmú rosszabbodást jelez, s különösen a lányok kedvezótlen szerfogyasztásának emelkedố tendenciái figyelemfelhívóak. Az alkoholfogyasztás kapcsolatot mutat az iskolatípussal, a családi szerkezettel, a 
családi élet minóségével és az elidegenedés érzésével. Paksi Borbála és Demetrovics Zsolt tanulmánya lehetôséget teremt arra, hogy a magyarországi tiltott szerek fogyasztási arányát tágabb kontextusban, más európai országok fogyasztási arányaival, illetve az elmúlt években megmutatkozó fogyasztási adatok alakulásának mintázatával vethessük össze. A szerzók ráirányítják a figyelmet arra, hogy az eredmények értelmezésénél nem szabad elfelejtenünk, hogy az iskolai osztályokban végzett kutatásokból kimaradnak a feltételezhetôen leginkább problémás szerhasználók, azok, akik az iskolából is kimaradva töltik napjaikat. A prevenciós programoknak viszont szükségszerúen ezt a populációt is érdemes a jövôben megcéloznia és elérnie.

A negyedik rész az egészségpszichológiai ismeretek gyakorlatba való átültetésének és alkalmazási módjainak fontosságáról, kutatási eredményeinek lehetőség szerint minél pontosabb hasznosításáról győz meg bennünket. Ebben a részben a pedagógiai-pszichológiai ismeretek alapján kidolgozott, hazánkban is alkalmazott vagy hazai fejlesztésú primer prevenciós programok alapelveiból, múködési lehetóségeiból kapunk ízelítôt.

Az egészségpszichológia viszonylag új, szúk három évtizedes múltra visszatekintó ága a pszichológiának. A pszichológia módszereit és eszköztárát alkalmazza az egészség fejlesztésére, a betegségek, megelózésére és kezelésére, a fizikai betegségek hátterében álló pszichológiai és viselkedéses tényezók azonosítása érdekében, az egészségügy rendszerének kritikájára és fejlesztésére, valamint az egészségpolitika formálására.

Az egészségpszichológia létrejöttének és gyors fejlődésének az egyik leghangsúlyosabb motorja az alkalmazott jellege, az a törekvés, hogy a tudást képes gyakorlattá konvertálni. Az egészségpszichológia kezdetben elsósorban az orvosi területeken jelent meg, ugyanakkor széles perspektíváját jelezte, hogy egyik fó feladatának azt tekintette, hogy a mentális betegségeken túlmenóen a szomatikus betegségek esetében megjelenó pszichológiai problémák kezeléséhez is segítséget nyújtson. Ezt a szemléletváltozást támogatta az a párhuzamos fejlódés, amely a prevenció felól haladt az egészségmegôrzés, majd az egészségfejlesztés felé. A fejlődés lényege abban a felismerésben áll, hogy nem csupán a negatív tényezók (betegség, viselkedészavar, droghasználat stb.) megelôzése, hanem az egészség megőrzése, sôt az egészség fejlesztése a fó feladat, vagyis a szerzett potenciál megerôsítése és növelése a végsó cél.

Az egészségpszichológia egyik fontos vizsgálati szempontja a vizsgált jelenségkör színtér-megközelítése. Az emberi élet egyik legfontosabb korai színtere az iskola. Az iskola és a serdülókor egészségpszichológiája elválaszthatatlan, hiszen a gyermekek és a serdülók idejük jelentốs részét 
az iskolában töltik, az iskola a kortárs kapcsolatok legfontosabb forrása, $\mathrm{s}$ az iskolához fúződó viszony protektív tényezóként szolgálhat számos problémás viselkedéssel szemben. A gyermekkor és a serdülókor kiemelt jelentóségú az egészség és a betegség szempontjából, mivel ebben az idôszakban alakulnak ki és alapozódnak meg a kedvezó egészségmagatartások és a kedvezótlen, egészséget veszélyeztetô magatartásformák is. A megfeleló iskolai környezet kritikus szerepet játszhat a hátrányos helyzetú vagy deviáns gyermekek egészséges fejlődésének biztosításában. A kötet követi azt a fajta komplex szemléletet, amely figyelembe veszi az iskola társas és környezeti tényezóit is.

Az iskolák felismerték a testi és lelki egészségre nevelés fontosságát. A pedagógia és a pszichológia között új érintkezési és együttmúködési felületek nyílnak meg. A pedagógia és a lélektan fokozatos közeledése és átfedése sem csökkenti a pedagógia diszciplináris és szerkezeti önállóságát, hiszen az iskolai nevelés továbbra is hagyományos iskolai rendszerben zajlik, és fontos társadalmi funkciót teljesít, a társadalmi kulturális átörökítés és a társadalmi beilleszkedés intézményes eszköze. Az egészséglélektan újszerú nevelési modellt kínál a megszokott általános nevelési célok mellett (erkölcsi értékek, önkontroll, együttmúködési készség stb.), lehetôséget adva a diákok számára a speciális kognitív és motivációs készségek, az önhatékonyság, új attitúdök, kommunikációs módok elsajátítására.

Az egészséglélektan egyik vonzó vonása a cselekvésorientáltsága, az a törekvése, hogy az elméleti háttér egyszerúbb - „felhasználó barát” - formában jelenik meg. A modern egészséglélektan sok eszközt birtokol céljainak megvalósítására: teszt, kérdőív, kampányforma, kísérleti elrendezésú beavatkozás. Fontos a pozitív modellhatások erósítése, a kortárscsoportok pozitív referenciacsoportként ható múködésének elősegítése.

Természetesen az iskolák igénybe vehetnek külsố segítséget is egészségpszichológus szakember személyében, de a legegyszerúbb a saját erôforrások használata. Az iskolai közegben megtalálhatók már azok a szereplók, akik bevonhatók, mozgósíthatók az egészségfejlesztó munkába. Ilyen feladatokat láthat el (az iskola már meglévô eróforrásaira építve) az iskolapszichológus, az osztályfőnök, az iskolai drogreferens, a vallástanár, a múvészeti-, médiatanár, vagy akár a testnevelő tanár. Ehhez persze az iskolán belül szervezetkonzultációra, szervezetfejlesztésre lehet szükség.

A prevenciós beavatkozásokat - szakítva a korábbi elsódleges, másodlagos, harmad-lagos prevenció felosztással - manapság egyre inkább szokás aszerint felosztani, hogy a probléma megjelenésének mely fázisában alkalmazzuk, illetve hogy azok milyen veszélyeztetettségú csoportokat céloznak meg. Eszerint beszélhetünk univerzális prevencióról, amely az általános populációt célozza meg, de nem veszi figyelembe, hogy a fiatalok egy 
része a probléma kialakulásának a szempontjából veszélyeztetettebb, mint mások. Ezzel szemben a szelektív prevenció pontosan azokat a személyeket vagy csoportokat célozza, akik valamilyen jellemzójüknél fogva (alkoholista szülők, kedvezótlen környezeti tényezók) kiemelten veszélyeztetettek a probléma kialakulása tekintetében. Az indikált prevenció azokat célozza, akiknél ugyan az addikció kritériumai nem teljesülnek, de a probléma kialakulásának kezdeti jelei már megjelentek (pl. kísérletezés az illegális szerekkel). Hazánkban, de a világ más országaiban is az iskolai színtéren zajló univerzális prevenció vált a legelterjedtebb prevenciós beavatkozási móddá. Ennek oka feltehetôleg jelentôs mértékben az lehet, hogy ezek a programok viszonylagosan olcsón képesek nagy tömegeket elérni. Az elmúlt évtizedek kutatásait áttekintve Cuijpers (2004) rámutat arra, hogy az univerzális iskolai programok közül az interaktívak (ahol nem didaktikus előadás, hanem a diszkusszió áll a középpontban; adott a szerepjáték lehetősége; stb.), ha kis mértékben is, de képesek a pszichoaktívszer-használat befolyásolására. Fontos azonban tisztában lennünk azzal, hogy ezek a programok jellegükból fakadóan inkább a kipróbálás mértékét, mintsem a problémás használatot képesek befolyásolni.

Végül fontos kiemelni, hogy szükség van az oktatott anyag minóségbiztosítására és eredményvizsgálatokra - ez világviszonylatban is gyenge pont. Itt mutatkozik meg leginkább, hogy a klasszikus pedagógia és a hagyományos iskolaszerkezet milyen nehezen tudja befogadni, és ellátni a testi-lelki egészséggel kapcsolatos teendóket. Az egészséglélektan másik kiemelt alkalmazási területe a pedagógusok lelki egészségvédelme, hiszen nekik is egészségpszichológiai képzésben kell részesülniük. A segítók és fejlesztők kiégés elleni védelmét az egészségtan fontos feladatának tekinti.

Az egészséglélektanban napjainkban mind nagyobb szerepet kap a pozitíu pszichológia. Célja, hogy ne csak a betegségek eliminálására vagy megelôzésére irányuljon a figyelem, hanem az egészség tartós fenntartására, amelynek feltétele a személyiség kiteljesedése, az optimizmus, önhatékonyság, az „áramlásos” boldogságszerú lelkiállapot (flow), és a problémákkal szembeni ellenálló képesség (resiliencia). A pedagógusok hitelességéból, érettségéból eredó modellhatás lehet a versenykésztetés, a lemaradásból eredó büntetés érzés helyett a kontingencia-elv szerinti jutalmazás, a fejlesztô énátélés (self experience), az önhatékonyságot erôsítő kompetenciatréning és készséggyakorlás, a társas részvétel élménye.

Az iskola ma a pszichológiai fejlesztés és a korrektív viselkedés-változtatás legfontosabb társadalmi színtere. A szervezeti struktúrában a pedagógusokon kívül mind több segítố szakember is helyet kap. A pedagógiai munkában is nó a pszichológiai szempontok szerepe. A nevelés céljai kö- 
zött növekvő mértékben kapnak hangsúlyt az egészségnevelés, a prevenció, a mentálhigiéné feladatai.

Összefoglalásként: a kötet a 2005-ös „II. Egészségpszichológiai találkozó: Iskola és egészségpszichológia" tematikus címet viseló konferencián elhangzó előadásokat tartalmazza, amelyet készítói szerkesztett kötetet formájában tárnak az olvasó elé. A könyv az egészségpszichológiát hivatott bemutatni, amely a pszichológiának viszonylag új, három évtizedes múltra visszatekintő ága. A kötetben a pedagógiai-pszichológiai ismeretek alapján kidolgozott, hazánkban is alkalmazott vagy hazai fejlesztésú primer prevenciós programok alapelveiból, múködési lehetőségeiból, és az ezekhez kapcsolódó kutatásokból kapunk aktuális ízelítót. Az egészségpszichológia révén a pedagógia és a pszichológia között új érintkezési és együttmúködési felületek nyíltak meg. Az egészséglélektan újszerú nevelési modellt kínál a megszokott általános nevelési célok mellett. Az egészségpszichológia létrejöttének és gyors fejlődésének az egyik leghangsúlyosabb motorja az alkalmazott jellege, az a törekvés, hogy a tudást képes gyakorlattá konvertálni. Az iskolai egészségfejlesztó programok közül azok hatékonyabbak, amelyek interaktívak. Ezek nem didaktikus elóadásra építenek, hanem lehetóséget adnak a diszkusszióra, a szerepjátékos feldolgozásmódra. Az interaktív programok, ha kis mértékben is, de képesek a pszichoaktívszer-használat prevenciójára a kipróbálás fázisában (vagy elótte). Az egészséglélektanban napjainkban mind nagyobb szerepet kap a pozitív pszichológia, amelyról a kötetben definíció értékú meghatározásokat kapunk, valamint bemutatásra kerül, hogy hogyan használható fel szemlélete az iskolai egészségpszichológiában. Végül a kötet sok helyen kitér a pedagógusok egészségpszichológiai képzésére, ez irányú készségeik növelésére, és lelki egészségük védelmére.

\section{Dr. Petốvári Csaba}

PhD hallgató

Semmelweis Egyetem, Magatartástudományi Intézet

1089 Budapest, Nagyvárad tér 4.

E-mail: csabapetovari@gmail.com 
Rainer Schandry: Biologische Psychologie

2., átdolgozott kiadás, CD-ROM melléklettel

BeltzPVU, Weinheim, 2006, 666 oldal, ára: 52,90 EUR

ISBN 3-621-27590-8

A könyv megrendelése azért merült fel, mert „Neuropsychologie” tantárgyunkhoz az orvosi karon megfelelố tankönyvet keresünk. Nemrégiben recenzáltuk Birbaumer kiváló tankönyvét a Springer kiadó gondozásában, melyet igen sokoldalúan használhatnak a pszichológia neurobiológiai, élettani háttere iránt elmélyültebben érdeklődők; részletessége, terjedelme azonban megnehezíti a tankönyvként történó használatot - legalábbis a mi tantárgyi kereteink között.

Napjainkban a különféle irányzatok általános törekvése a pszichológia minél szélesebb biológiai megalapozása (ez még a szociálpszichológiában is érezteti hatását, aminek példája Susan Fiske magyarul nemrégiben megjelent tankönyve). Ez a tendencia a gyakorlati alkalmazásokban, pl. a klinikai pszichológiában is érezhetó, miután a pszichológiai jelenségek (pl. a tanulás, az érzelmek, a motiváció, s a pszichés zavarok) megértésében egyre növekszik a neurobiológia eredményeinek jelentósége. Érdekes, hogy a tudományos pszichológia kezdeteit kifejezett biológiai orientáció jellemezte (pl. Wilhelm Wundt is ebben a tárgykörben írta elsó jelentôs múveit), s csak hosszas csendet követóen, a biológia és az idegtudományok utóbbi évtizedekben tapasztalható rohamos fejlődésével vált ismét jelentőssé a megközelítés.

Jelen kötet szerzóje a müncheni egyetem pszichológia professzora, kötetét elsósorban pszichológiát, s azon belül is a biológiai (élettani) pszichológiát hallgatók, valamint orvostanhallgatók és érdeklődő laikusok számára írta.

A fejezetek íve a genetikai, a molekuláris és sejtszint, majd a központi és perifériás/vegetatív idegrendszer, a hormonális rendszer ismertetésével kezdődik. Egyetlen fejezet foglalkozik a mozgásszervek múködésével és a motoros múködések idegrendszeri hátterével. A fejezetek következő csoportja a percepció különbözó modalitásait tárgyalja. A fejezetek sora egy általános érzékeléspszichológiai bevezetóvel kezdődik. Ezt követi a szomatoszenzoros észlelésról, a látásról, a hallásról, az egyensúlyérzékelésról, az ízlelésról, a szaglásról, a fájdalomról szóló fejezet.

A könyv második felében a viselkedés szintjéhez közelebb álló témaköröket találunk. Egy-egy fejezet foglalkozik a stresszel, a szexuális viselkedéssel, majd a cirkadián ritmusokkal, az alvás és álom jelenségeivel. A sorban a pszichés zavarokban fontos transzmitterváltozásokat és a pszicho- 
farmakológiai kezelési lehetôségeket ismertetô, majd a drogfüggôségekról szóló fejezet következik. Ezt követóen olvashatunk az érzelmek, illetve a tanulás/emlékezet neurobiológiai hátteréról. A sort a nyelvvel és a féltekei lateralizációval, majd a vizsgálati, módszertani lehetőségekkel foglalkozó fejezet zárja.

A szerzố a biológiai pszichológia területén barangolva jó érzékkel egyensúlyoz a tudományos megalapozottság és pontosság, valamint az érthetôség között. Az egyes fejezeteket úgy építette fel, hogy nem vár el az olvasótól elmélyültebb biológiai és orvosi ismereteket, mégis az egyes témák teljességgel történó bemutatására törekszik. A tankönyv tartalmilag a „biológiai pszichológia" két féléves tárgyának tematikáját öleli fel, de tárgyalásmódja mindig túlmutat a szúkebb határokon, pl. neurológiai, pszichiátriai betegségek bemutatásával segíti a komplex összefüggések jobb megértését.

A könyv egésze tankönyvi célokat szolgál. Ez leginkább a könyvhöz mellékelt kiegészítô anyagokból látható. A könyvhöz az alapfogalmakat meghatározó részletes glosszáriumot szerkesztett a szerzó. A mellékelt CD-ROM-on a tanulást segító fogalomtárat, összefoglalásokat, tesztkérdéseket, s a könyv teljes ábraanyagát is megtalálhatjuk, melyek kiválóan használhatók az ismeretek megbízható elsajátításában, s a vizsgára történó felkészülésben.

A kötet olvasását könnyíti, hogy a szerző - bár szisztematikusan természettudományos ismereteket is bemutat - nem vész el a kísérletek, vizsgálatok részleteiben, s elsósorban humán vonatkozású eredményekre alapoz. A fószövegben csak elszórtan találhatók irodalmi hivatkozások, s a végén közölt irodalomjegyzék is csak a téma legfontosabb, már klasszikusnak tekinthetó forrásairól ad áttekintést. Ezt a megközelítést egyébként egyre több tankönyvben látjuk napjainkban, amikor az elektronikus adatbázisok bárki számára gazdag és naprakész keresési lehetôséget biztosítanak.

A könyv szövegét színes szövegdobozokba szerkesztett „Összefoglalások”, ,Részletezések”, s „Betegség-ismertetések” tagolják, melyek önmagukban is olvashatók, használhatók.

Schandry könyvének fó erénye közérthetố stílusa, s a témák tárgyalásának szemléletessége, elevensége. Úgy lehet belóle megtanulni a pszichológia - sokszor nem könnyen elsajátítható - biológiai alapjait, hogy a tanulás élvezetessé válik.

\author{
Dr. Tiringer Istuán \\ PTE ÁOK Pszichiátriai és Orvosi Pszichológiai Klinika \\ 7624 Pécs, Szigeti út 12. \\ E-mail: istvan.tiringer@aok.pte.hu
}

